\title{
土木関連シール材
}

鈴 木 秀 一*

\section{Seal Materials for Civil Engineering}

Hideichi SUZUKI (Hayakawa Rubber Corporation, Technical and Development Department, 5351 Minamigaoka, Minoshima, Fukuyama, Hiroshima 721-8540, Japan)

Many joints exist in the huge concrete structures. These joints tend to be a weak point of the concrete structures. Especially the leakage of water from the joints in an underground structure and a water processing structure causes the decrease of durability of the structures. Many running costs are needed to prevent the leakage of water and to maintain the durability of the structure. Therefore, seal of the joints is very important.

This paper describes seal materials in a construction joint and an expansion joint to the concrete structures.

Key Words : Seal materials, Waterstops, Construction joint, Expansion joint, Hydrophilic rubber

\section{1.は じめ め}

一体化されているかに見える巨大なコンクリート構造物 にも，実は多くの継目が存在する．これらの継目はコンク リート構造物の弱点となりやすく, 特に地下構造物, 水処 理構造物における漏水は耐久性の低下だけでなく, ランニ ングコストが増えるため継目の止水対策は重要な課題であ る. そこで，目的に応じて各種ゴム・エラストマー製品が 止水材として用いられている.

本稿では，それらのゴム・エラストマー製品について紹 介する。

\section{2. 止水材の種類}

\section{1 施工継目 (Construction Joint)}

コンクリート躯体を現場で築造する時, 底版 - 壁・頂版 のような部位ごとにコンクリートを打設するため水平・垂 直面に継目が生じる。また運搬可能な大きさに分割された コンクリート部材を工場で製作し，現場にてボルト等で連 結し組み立てる場合にも継目が生じる.

これらを施工継目と呼び, 継目の目開きは数 $\mathrm{mm}$ 程度以 下であるが, 水圧が高い地下構造物や水処理構造物では止 水対策が必要である.

図 1 は半地下式の現場打ちコンクリート水槽の断面図に 継目位置を示したものであり，底版コンクリートを 2 回に 分け打設し, 壁も各部位ごと同じく 2 回打設した場合の施 工継目の例である.この場合の止水工法としては, 埋め达

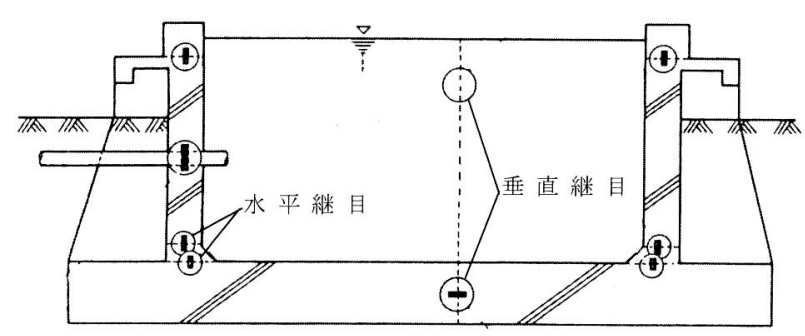

図 1 継目位置

み工法と挿入工法に大別される。

先打ちコンクリートと後打ちコンクリートの打継部の中 央に不透水性の板を設置して水路を遮断する方法が埋め込 み工法であり，塩化ビニル止水板が多く用いられる．非加 硫ブチル止水板(鉄板入り)は同じく埋め込み工法であるが, コンクリートとブチルゴムが化学反応により接着するため コンクリートと止水板の界面にすき間が生じず，高度な止 水が可能である.

図 2 に埋め込み工法例を示す. 左上図と右写真は壁コン クリートを打設する前に底版コンクリートに塩化ビニル止 水板を埋め达んだ状態，左下図は製品断面を示したもので

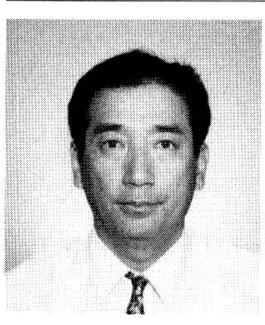

*早川ゴム侏技術部 ( テ 721-8540 福山市箕島 町南丘 5351 番地) 課長. 昭和 52 年, 東京都立 大学工学部土木科卒業. 平成 2 年, 早川ゴム (制入社, 現在に至る. 専門は土木工学. 
ある。

挿入工法は先打ちコンクリートの硬化後に打継部中央に 水膨張ゴム止水材をくぎ止め又は接着剂により固定し，そ ののち後打ちコンクリートを打設するもので，侵入水によ る水䐍張ゴム止水材の吸水䐍張圧で止水する工法である.

図 3 に挿入工法の施工例を示す。図左は先打ちコンクリ 一トに水膨張ゴム止水材を接着郕とくぎ止めにより固定し た状態の側面図と断面図，図右は標準的な水膨張ゴムの製 品断面寸法図である.

また工場で製作され現場で組み立てるプレキャストコン クリート製品の場合，スポンジゴム単体又はスポンジゴム の外側に粘着性ブチルゴムを被覆したものや水膨張性ゴ ム, 加硫ゴムガスケットの圧縮復元力で止水する工法が用 いられる。

道路等の地下に埋設される矩形のコンクリート水路およ び通路として用いられるボックスカルバートは個々の製品 を鋼材等で締結し一体化させる，各継目にはスポンジゴム 単体又はスポンジゴムの外側に粘着性ブチルゴムを被覆し たシール材を圧縮することですき間を充てんし止水する。 図 4 にボックスカルバートの施工例と止水部詳細, 止水材 の断面形状を示す ${ }^{1)}$.

継目幅の施工誤差を $5 \mathrm{~mm}$ 程度考慮しシール材を 50 〜 70 \%圧縮するようシール材と溝寸法を設計し，一般的に は水圧 $0.1 \mathrm{MPa}$ 以下の条件で使用する.

シールド工法は近年の地下鉄, 下水道トンネルなどに多

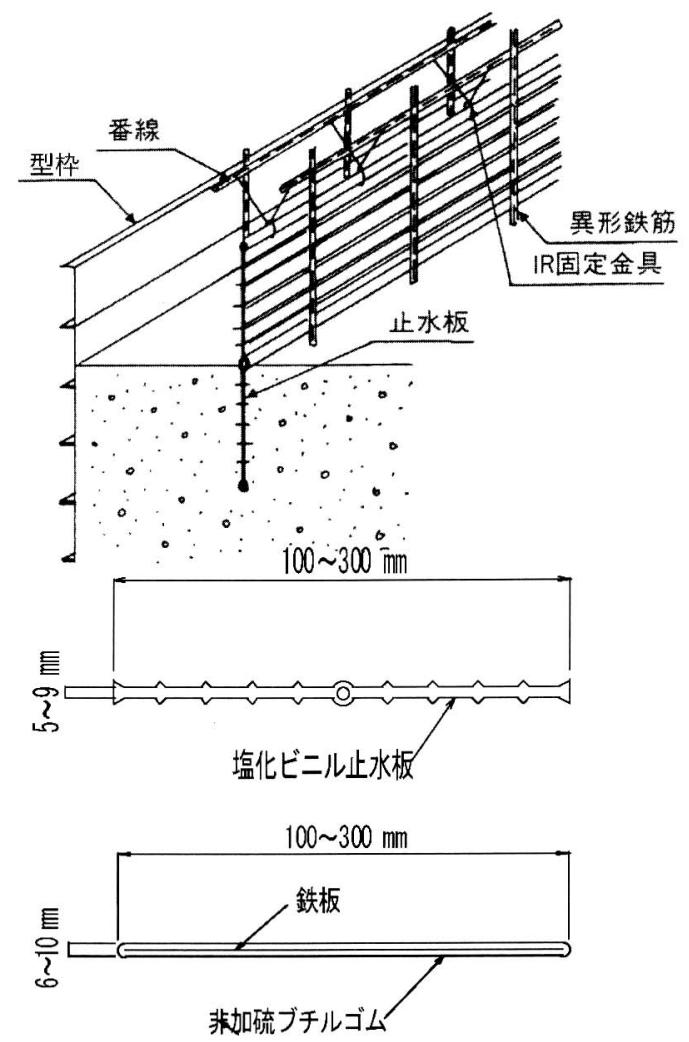

く採用されている工法である。トンネルはシールドマシン によって掘削され円形の断面をもち，トンネル本体が分割 されたセグメント(ブロック)を組み上げることによって構 築される.

シールドセグメントも個々のセグメントをボルトにより

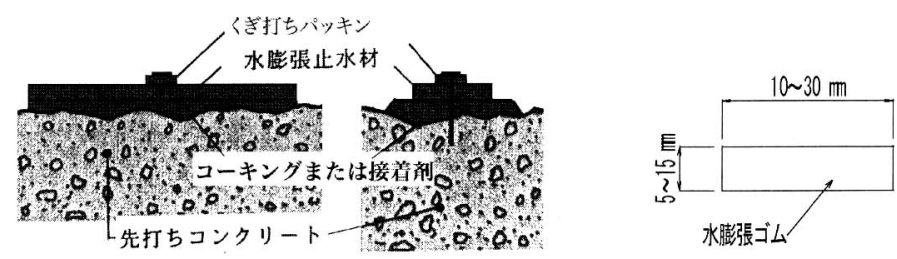

図 3 挿入工法例
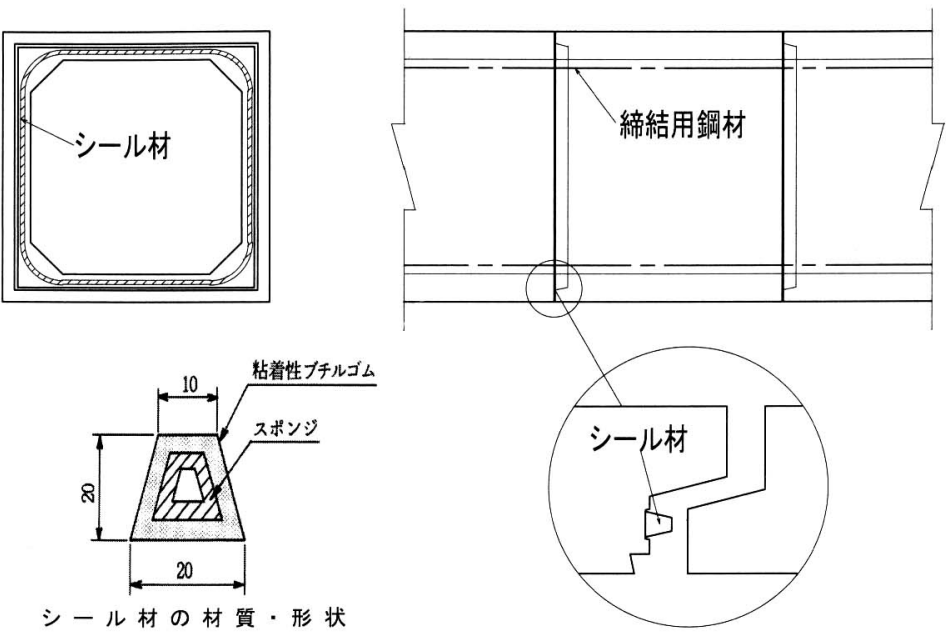

図 4 ボックスカルバートの施工例と止水部詳細

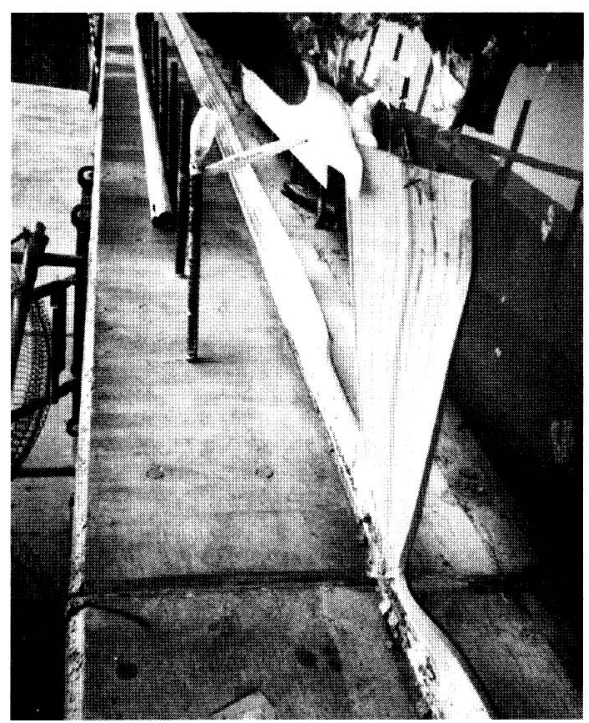

塩 ビ板の施工状 況 


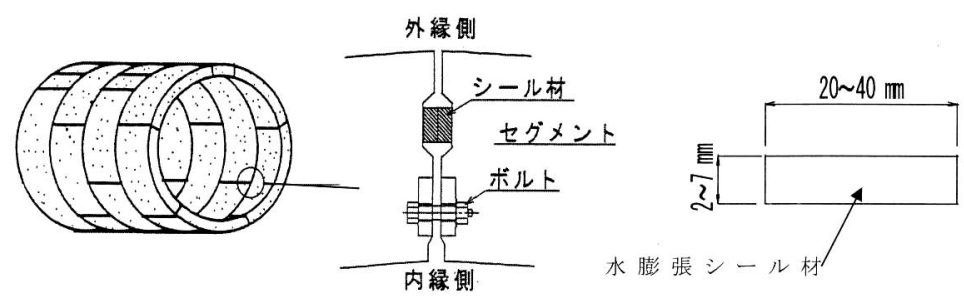

図 5 シールドセグメントの施工例と止水部詳細

締結するが，シールドマシンはシールドセグメントを組み 立てたトンネル自体を反力として油圧ジャッキにて押しな がら推進していく，そのためシール材には大きな圧縮力が 働くが，スポンジゴム単体又はスポンジゴムの外側に粘着 性ブチルゴムを被覆したシール材等ではジャッキを戻した 時にすき間が生じるので適さない。そこで若干のすき間が 生じても膨張圧で止水できる水膨張性ゴムシール材が用い られることが多い. シールドセグメントの施工例と止水部 詳細，止水材の断面形状を図 5 に示す ${ }^{2)}$.

水膨張性ゴムシール材に要求される性能条件として以下 の項目を挙げることができる.

○吸水膨張後も適度な膨張圧を保持していること.

○長期間の浸し及び吸水・乾燥の繰り返し後も膨張倍率が 低下しないこと。

○コンクリートアルカリ水, 塩水等の接触溶液に対しても 膨張倍率が確保されること.

○セグメント組み立て時，シールドジャッキによる圧縮圧

に耐えること。

図 6 は目開きごとの浸し日数と止水圧力の関係を示した ものである．目開きがゴム厚以上の場合すき間が生じ当初 漏水する，しかし水膨張性ゴムシール材が吸水膨張するこ

表 1 水澎張性ゴムの物性值例

\begin{tabular}{c|c|c|c}
\hline \multirow{2}{*}{ 測定項目 } & \multirow{2}{*}{ 試験方法 } & \multicolumn{2}{|c}{ 物性值 } \\
\cline { 3 - 4 } & & 水膨張前 & 水膨張後 \\
\hline 引張強さ & JIS K 6251 & $0.4 \mathrm{MPa}$ 以上 & $1.0 \mathrm{MPa}$ 以上 \\
\hline 切断時伸び & JIS K 6251 & $800 \%$ 以上 & $800 \%$ 以上 \\
\hline 硬さ & JIS K 6253 & $\mathrm{A} 44$ & $\mathrm{~A} 32$ \\
\hline 比 重 & JIS K 7112 & 0.9 & - \\
\hline 体積膨張倍率 & - & - & $2 \sim 5$ 倍 \\
\hline
\end{tabular}
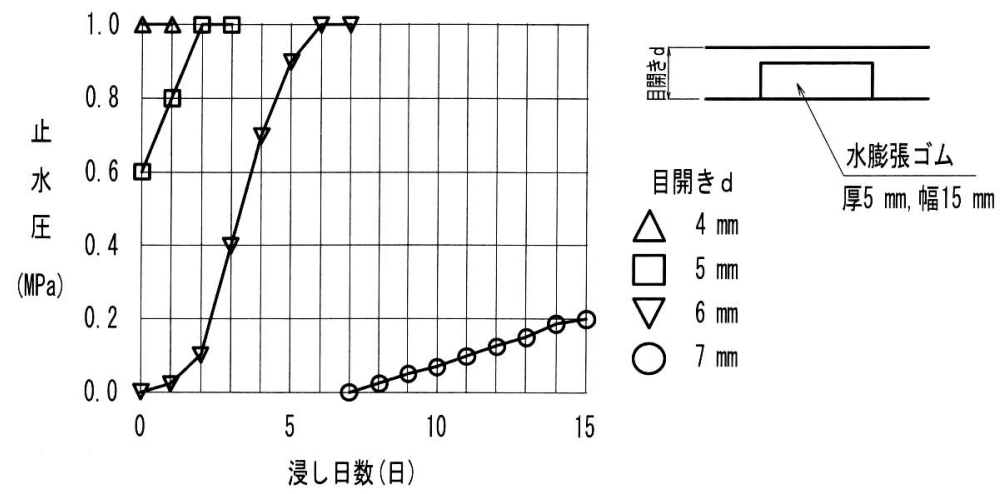

\section{$\triangle 4 \mathrm{~mm}$}

$\square 5 \mathrm{~mm}$

$\nabla 6 \mathrm{~mm}$

○ $7 \mathrm{~mm}$

図 6 目開きと浸し日数による止水性能例 
ている.

(1)引張, せん断強度が高い.

(2)伸長率が大きい.

(3)耐寒温度が低い。

(4)コンクリートとの付着力が高い.

(5)施工性が良い.

建物の構造上また地盤条件や地震など設計計算上 100 $\mathrm{mm}$ を超える大きな継目変位量が想定される場合は, 図 10 のような角型可とう継手が用いられる ${ }^{4)}$.

伸縮ゴム端部を取付枠材・押え板 (鋼板)にて挟みボル ト・ナットで締結し止水するとともに伸縮ゴムの $\Omega$ 型形状

表 2 ゴム止水板の物性規格值例

\begin{tabular}{|c|c|c|c|c|}
\hline \multirow{2}{*}{\multicolumn{2}{|c|}{ 測定項目 }} & \multicolumn{2}{|c|}{ 物性規格値 } & \multirow{2}{*}{ 試験方法 } \\
\hline & & NR · SBR系 & CR · EPDM系 & \\
\hline & 硬 ざ & $65 \pm 5$ & $63 \pm 5$ & JIS K 6253 \\
\hline \multicolumn{2}{|r|}{ 引張強さ } & $19.6 \mathrm{MPa}$ 以上 & $14.7 \mathrm{MPa}$ 以上 & JIS K 6251 \\
\hline \multicolumn{2}{|r|}{ 伸 び } & 400 \%以上 & 350 \%以上 & JIS K 6251 \\
\hline \multirow{2}{*}{$\begin{array}{l}\text { 老 } \\
\text { 訛 } \\
\text { 試 } \\
\text { 験 }\end{array}$} & $\begin{array}{l}\text { 引張強さ } \\
\text { 変 化率 }\end{array}$ & $-20 \%$ 以内 & $-20 \%$ 以内 & \multirow{2}{*}{$\begin{array}{l}\text { JIS K } 6257 \\
70{ }^{\circ} \mathrm{C} \times 144 \text { 時間 }\end{array}$} \\
\hline & $\begin{array}{l}\text { 伸 び } \\
\text { 変化率 }\end{array}$ & $-20 \%$ 以内 & $-20 \%$ 以内 & \\
\hline
\end{tabular}

で変位に追従する止水板であり, 高水圧下では伸縮ゴムに 繊維を積層したものが使用される。このタイプは止水板を コンクリートに埋め込むのではなく，コンクリート表面に 露出するためメンテナンスが可能である.

コンクリート壁中に埋め込まれるため温度，紫外線等の 劣化要因が少ない環境で使用されるゴム止水板はNR・ SBR系が用いられ，使用環境の厳しさが想定される角型 可とう継手はCR 又は EPDMが一般的であり，物性規格值 の例を表 2 に示す.

下水道施設のコンクリートマンホールと管きょ等の異種 材料の接合部も地震時の弱点になりやすいため, 図 11 の ようなゴム性可とうジョイントが用いられている.

要求性能としては $0.1 \mathrm{MPa}$ 水圧下で管長の $1.5 \%$ (塩化ビ ニル管 1 本の長さが $4 \mathrm{~m}$ の場合は $6 \mathrm{~cm}$ )の伸び変位に追従 できることが求められる.

\section{3. ゴム止水板の設計}

ゴム止水板の役割は地震や地盤の不同沈下でコンクリー 卜構造物の継目に目開きが発生した場合でも漏水しないこ とであるが，コンクリート構造物の耐用年数は一般的には
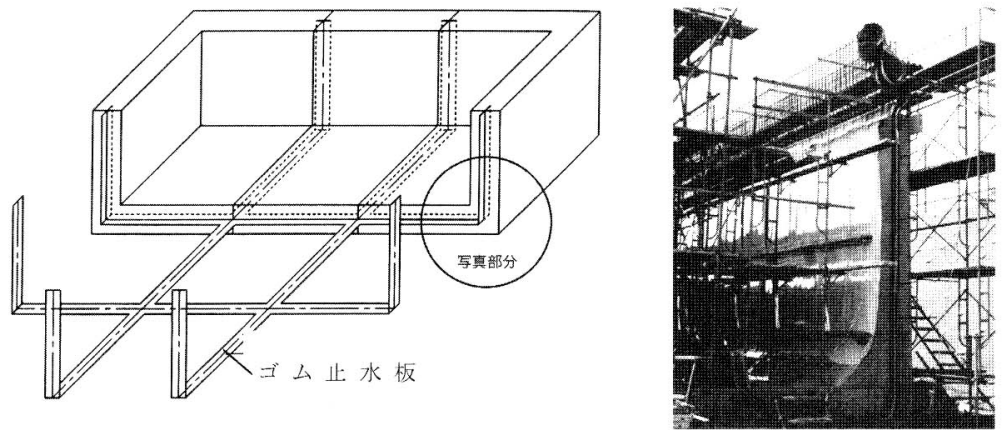

図 9 ゴム止水板の施工例
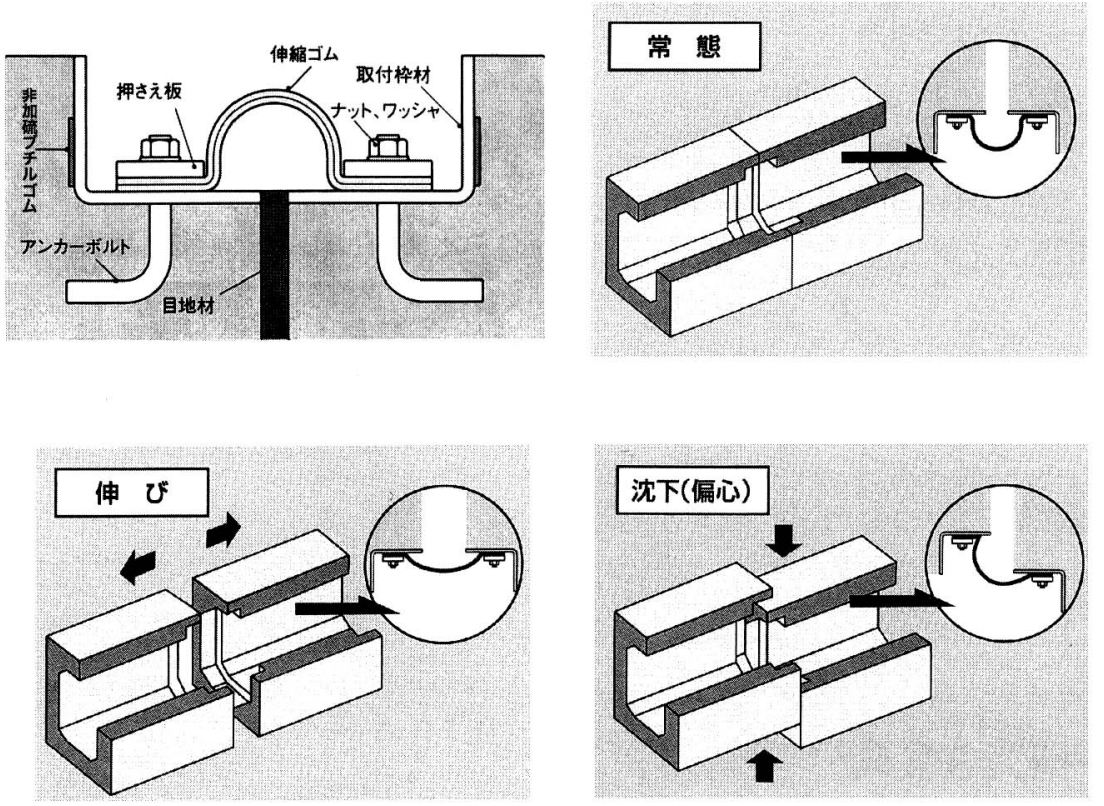

図 10 角型可とう継手断面及び変位状況 


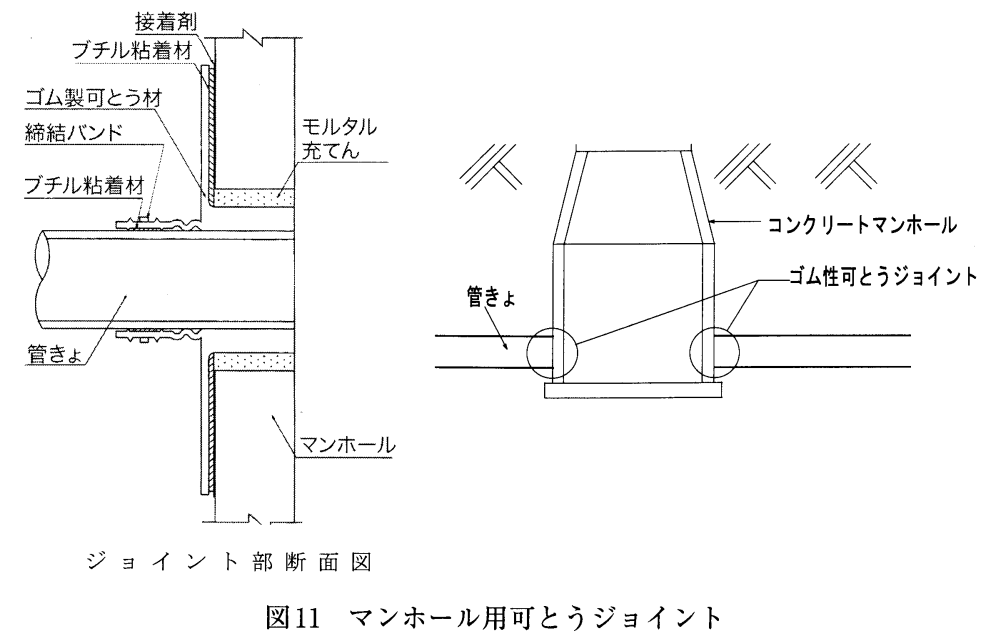

$40 \sim 60$ 年といわれており，ゴム止水板はコンクリート構 造物と同等以上の耐久年数を有することが望ましい.

ゆえに短期的な耐圧性能のみにとどまらず長期のクリー プ性能が重要であり, 長期水圧試験における収束時の発生 ひずみの結果を基にゴム止水板の伸び率 $40 \%$ 以下で使用 するよう設計している5).

またゴム止水板の最大変位量はセンターバルブ部の形状 による余裕で決まるが, 許容変位量と耐水圧は想定最大水 圧と目地幅で決まり, 図 12 の薄肉円筒理論式を用いゴム

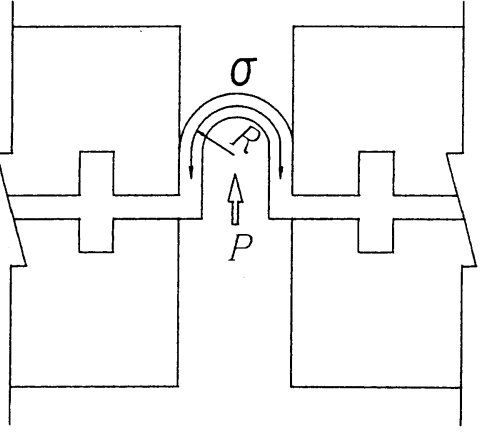

図 12 薄型円筒理論式のパラメータ の伸び率 $40 \%$ を超えない張力の範囲で使用する.

\footnotetext{
$\sigma=P \cdot R / \mathrm{t}$

$\sigma ;$ ゴムに働く張力

$R$; 圧力を受ける半径

$\mathrm{t} ;$ :ゴムの厚さ

$P$; 水圧
}

\section{4.おわりに}

今回は地下及び水処理構造物など漏水対策が必要な土木 コンクリート構造物の継目に使用される止水材について述 ベたが，近年の都市集中化による地下空間利用の増加，上 下水道処理施設の大型化等により需要は確実に増えるとと もに，耐震対策として高機能な製品が求められている.

今後とも更なる改良, 新材料及び工法の開発が望まれる.

\section{References}

1 ) "Reinforced Concrete Box Culvert Douro Maisetu Sisin", Zenkoku Box Culvert Kyoukai, Tokyo, p.35 (1991)

2 ) "Segument Seal Zai ni Yoru Sisui Sekkei Tebiki", Nippon Tonnel Gijyutu Kyoukai, Tokyo, p.31 (1997)

3 ) "Kyoudoukou Sekkei Sisin", Nippon Douro Kyoukai, Tokyo, p.48 (1986)

4 ) "Kakugata Katoutugite Gijyutu Siryou", Kakugata Katoutugite Kenkyukai, Tokyo, p.3 (1999)

5 ) "Gomu Sisuiban Gijyutu Siryou", Gomu Sisuiban Kenkyukai, Tokyo, p.7 (1998)

\section{日本語表記参考文献}

1）鉄筋コンクリート製プレキャストボックスカルバート道路埋設 指針，全国ボックスカルバート協会，東京，p.35 (1991)

2 ) セグメントシール材による止水設計手引き，日本トンネル技術 協会, 東京, p.31 (1997)

3 ）共同溝設計指針，日本道路協会，東京，p.48（1986）

4) 角型可とう継手技術資料, 角型可とう継手研究会, 東京, p.3 (1999)

5 ）ゴム止水板技術資料，ゴム止水板研究会，東京，p.7 (1998) 